Jurnal IImu Keperawatan Medikal Bedah 2 (2), November 2019, 1-51

ISSN 2338-2058 (print), ISSN 2621-2986 (online)

\title{
PENGARUH TEKNIK RELAKSASI OTOT PROGRESIF TERHADAP TINGKAT KECEMASAN PASIEN HEMODIALISIS DI RSUD WONOSARI
}

\author{
Cahyo Pramono*, Sri Sat Titi Hamranani**, Muhammad Yudha Sanjaya** \\ *) Program Studi S1 Ilmu Keperawatan STIKES Muhammadiyah Klaten, Kabupaten Klaten, Indonesia, email: \\ cahyo270812@gmail.com \\ **) Program Studi S1 Ilmu Keperawatan STIKES Muhammadiyah Klaten, Kabupaten Klaten, Indonesia \\ Corresponding Author: cahyo270812@gmail.com
}

\begin{abstract}
Abstrak
Penyakit ginjal kronik merupakan salah satu penyakit yang tidak dapat disembuhkan dan memerlukan terapi pengganti ginjal yang berlangsung seumur hidup. Hemodialisis merupakan salah satu terapi pengganti ginjal yang sering diterapkan kepada pasien penyakit ginjal kronik tahap akhir. Dalam menghadapi tahap - tahap dialisis, seringkali pasien hemodialisis merasakan kecemasan baik dari rentang ringan sampai dengan panik. Upaya yang dapat dilakukan perawat dalam mengatasi kecemasan pasien adalah dengan melakukan teknik relaksasi otot progresif. Penelitian ini bertujuan untuk mengetahui adanya pengaruh teapi relaksasi otot progresif terhadap tingkat kecemasan pasien hemodialisa di RSUD Wonosari. Metode penelitian ini menggunakan eksperimen kuasi dengan pendekatan one group pretest and posttest. Jumlah sampel dalam penelitian ini sebanyak 20 responden dengan pengambilan sampel menggunakan teknik purposive sampling. Uji statistik menggunakan uji wilcoxon untuk membandingkan antara nilain pre test dan post test. Hasil penelitian menunjukkan bahwa terapi relaksasi otot progresif memiliki pengaruh yang signifikan terhadap tingkat kecemasan pada pasien hemodialisis di RSUD Wonosari dengan nilai $p=0,0001(\alpha<0,05)$. Terapi relaksasi dapat dijadikan salah satu intervensi dalam mengatasi kecemasan pasien hemodialisis.
\end{abstract}

Kata kunci : penyakit ginjal kronik, hemodialisis, kecemasan, relaksasi otot progresif

\section{PENDAHULUAN}

Persatuan Nefrologi Indonesia (2016) menyatakan bahwa persentase diagnosa penyakit utama pasien hemodialisis di Indonesia terbanyak didominasi oleh penyakit ginjal kronis tahap akhir yaitu sebanyak 89\%. Prevalensi penyakit ginjal kronis di Indonesia berdasarkan sebesar $20 \%$ dan untuk D.I. Yogyakarta sebanyak 0,3\%.

Kecemasan merupakan salah satu hal yang sering dialami oleh pasien hemodialisis. Rasa cemas yang dialami pasien bisa timbul karena masa penderitaan yang sangat panjang (seumur hidup). Selain itu, sering terdapat bayangan tentang berbagai macam pikiran yang menakutkan Pramono, Hamranani , Sanjaya / Pengaruh Teknik Relaksasi Otot Progresif terhadap ... Page 22 of $\mathbf{5 1}$ 
Jurnal IImu Keperawatan Medikal Bedah 2 (2), November 2019, 1-51

ISSN 2338-2058 (print), ISSN 2621-2986 (online)

terhadap proses penderitaan yang akan terjadi padanya, walaupun hal yang dibayangkan belum tentu terjadi. Situasi ini menimbulkan perubahan drastis, bukan hanya fisik tetapi juga psikologis (Rahmi, 2008).

Kecemasan dapat diatasi dengan melakukan teknik relaksasi. Relaksasi digunakan untuk menenangkan pikiran dan melepaskan ketegangan. Salah satu teknik yang dapat digunakan untuk mengurangi kecemasan yaitu dengan menggunakan teknik relaksasi otot progesif (Suyamto, 2009). Teknik relaksasi otot progresif merupakan teknik relaksasi yang dilakukan dengan cara pasien menegangkan dan melemaskan otot secara berurutan dan memfokuskan perhatian pada perbedaan perasaan yang dialami antara saat otot rileks dan saat otot tersebut tegang (Kozier, B., Erb, 2011).

Relaksasi otot progresif dapat membantu seseorang merasa rileks ketika mengalami kecemasan. Hal ini diperkuat oleh penelitian yang dilakukan oleh Pailak et al (2013) tentang perbedaan pengaruh teknik relaksasi otot progresif dan napas dalam terhadap tingkat kecemasan pada pasien pre operasi di Rumah Sakit Telogorejo Semarang yang menunjukkan bahwa relaksasi otot progresif lebih efektif untuk menurunkan kecemasan pre operasi. Penelitian Alfiyanti, Setyawan, Argo, \& Kusuma (2014) menunjukkan bahwa relaksasi otot progresif juga efektif menurunkan tingkat depresi pasien yang menjalani terapi hemodialisis di RS Telogorejo Semarang.

Berdasarkan studi pendahuluan beberapa pasien di Unit Hemodialisis RSUD Wonosari mengalami tingkat kecemasan ringan hingga sedang ketika dilakukan tindakan hemodialisis. Kecemasan jika tidak ditangani dapat menimbulkan masalah psikologis pada pasien yang menjalani terapi hemodialisis. Rasa marah yang tidak diungkapkan akan diproyeksikan ke dalam diri sendiri dan menimbulkan rasa putus asa (Smeltzer \& Bare, 2002). Dari fenomena di atas peneliti tertarik untuk melakukan penelitian tentang pengaruh terapi relaksasi otot progresif terhadap tingkat kecemasan pasien hemodialisis di RSUD Wonosari. 
Jurnal IImu Keperawatan Medikal Bedah 2 (2), November 2019, 1-51

ISSN 2338-2058 (print), ISSN 2621-2986 (online)

\section{METODE PENELITIAN}

Desain penelitian ini yaitu eksperimen kuasi dengan pendekatan one group pretest and posttest, dimana hanya terdiri dari satu kelompok perlakuan yaitu diberikan terapi relaksasi otot progresif 1 kali dengan sebanyak 15 gerakan yang dimulai dari otot - otot wajah hingga otot - otot kaki dalam waktu 15 - 30 menit. Pengambilan sampel pada penelitian ini menggunakan teknik purposive sampling dengan kriteria inklusi yaitu pasien menjalani hemodialisis 2 kali dalam seminggu, usia 20-65 tahun, responden yang menggunakan akses vaskuler Arteriovenous (AV) Shunt atau Cimino-Brescia, dan memiliki kecemasan ringan dan sedang. Kriteria ekslusi pada penelitian ini adalah pasien yang mengalami penurunan kesadaran dan kram otot. Responden pada saat perlakuan jika terjadi komplikasi yaitu penurunan kesadaran dan kram otot akan dikeluarkan dari sampel (drop out).

Alat ukur yang digunakan untuk mengukur tingkat kecemasan dalam penelitian ini yaitu menggunkan kuisioner baku HARS (Hamilton Anxiety Rating Scale). Nursalam (2011) menyatakan bahwa kuisioner HARS adalah untuk menilai tingkat keparahan gejala kecemasan seperti suasana hati, ketegangan, gejala fisik, dan kekhawatiran.

\section{HASIL DAN PEMBAHASAN}

\section{A. Karakteristik Responden}

Tabel 1. Rerata Usia Responden di Unit Hemodialisa RSUD Wonosari Tahun $2018(\mathrm{n}=20)$

\begin{tabular}{cccccc}
\hline \multirow{2}{*}{ Variabel } & \multicolumn{5}{c}{ Rerata Usia Responden } \\
\cline { 2 - 6 } & $\mathrm{N}$ & Min & Maks & Mean & SD \\
\hline Usia & 20 & 24 & 63 & 45,15 & 12,062 \\
\hline
\end{tabular}

Berdasarkan tabel 1 menunjukkan bahwa rerata usia responden 45,15 12,062. 
Jurnal IImu Keperawatan Medikal Bedah 2 (2), November 2019, 1-51

ISSN 2338-2058 (print), ISSN 2621-2986 (online)

Tabel 2. Distribusi Frekuensi Responden berdasarkan Jenis Kelamin, Pekerjaan, Status Perkawinan, dan Pendidikan di Unit Hemodialisa RSUD Wonosari Tahun 2018 ( $\mathrm{n}=20)$

\begin{tabular}{|c|c|c|c|}
\hline No & Karakteristik Responden & $\mathrm{f}$ & $\%$ \\
\hline \multirow[t]{4}{*}{1} & Jenis Kelamin & & \\
\hline & a. Laki - Laki & 18 & 90 \\
\hline & b. Perempuan & 2 & 10 \\
\hline & Jumlah & 20 & 100 \\
\hline \multirow[t]{8}{*}{2} & Pekerjaan & & \\
\hline & a. Tidak Bekerja / Pensiunan & 4 & 20 \\
\hline & b. Petani & 3 & 15 \\
\hline & c. Wiraswasta & 5 & 25 \\
\hline & d. Pegawai Swasta & 3 & 15 \\
\hline & e. Pegawai Negeri & 1 & 5 \\
\hline & f. Buruh & 4 & 20 \\
\hline & Jumlah & 20 & 100 \\
\hline \multirow[t]{4}{*}{3} & Status Perkawinan & & \\
\hline & a. Kawin & 18 & 90 \\
\hline & b. Belum Kawin & 2 & 10 \\
\hline & Jumlah & 20 & 100 \\
\hline \multirow[t]{6}{*}{4} & Tingkat Pendidikan & & \\
\hline & a. $\mathrm{SD}$ & 3 & 15 \\
\hline & b. SMP & 6 & 30 \\
\hline & c. SMA & 9 & 45 \\
\hline & d. Perguruan Tinggi & 2 & 10 \\
\hline & $\begin{array}{l}\text { Jumlah } \\
\end{array}$ & 20 & 100 \\
\hline
\end{tabular}

Berdasarkan tabel 2 menunjukkan bahwa karakteristik responden berdasarkan jenis kelamin terbanyak ialah laki-laki sebanyak 18 orang (90\%). Sebagian besar responden bekerja sebagai wiraswasta sebanyak 5 orang (25\%), berstatus kawin sebanyak 18 orang (90\%), dan memiliki pendidikan SMA sebanyak 9 orang (45\%).

\section{1) Usia}

Berdasarkan hasil penelitian menunjukkan bahwa responden rata-rata berusia 45,15 $\pm 12,062$ tahun. Berdasarkan hasil laporan tahunan (Annual Report) dari Indonesian Renal Registry (IRR) per 31 Desember tahun 2017 yang menyatakan bahwa jumlah pasien aktif hemodialisa terbanyak berasal dari rentang usia 45-54 tahun dengan jumlah presentase 30,56\%. 
Jurnal IImu Keperawatan Medikal Bedah 2 (2), November 2019, 1-51

ISSN 2338-2058 (print), ISSN 2621-2986 (online)

Penyakit ginjal kronis semakin banyak menyerang pada usia dewasa muda. Hal ini dikarenakan pola hidup yang tidak sehat seperti banyaknya mengkonsumsi makanan cepat saji, kesibukan yang membuat stres, duduk seharian di kantor, sering minum kopi, minuman berenergi, jarang mengkonsumsi air putih. Kebiasaan kurang baik tersebut menjadi faktor risiko kerusakan pada ginjal (Dharma, 2014). Hal ini juga didukung dengan penelitan dari Tjekyan (2014) yang menyatakan bahwa faktor risiko yang berpengaruh secara signifikan terhadap kejadian penyakit ginjal kronik adalah riwayat hipertensi, riwayat diabetes melitus, riwayat infeksi saluran kemih, dan riwayat batu saluran kemih.

\section{2) Jenis Kelamin}

Berdasarkan hasil penelitan pada diketahui bahwa sebagian besar responden dengan jenis kelamin laki-laki sebanyak 18 orang (90\%). Berdasarkan data Riset Kesehatan Dasar (RISKESDAS) tahun 2013 menunjukkan bahwa prevalensi penderita penyakit ginjal kronik tertinggi terjadi pada laki-laki $(0,3 \%)$ daripada perempuan $(0,2 \%)$. Hal ini juga dipaparkan pada data Indonesian Renal Registry (IRR) dari Persatuan Nefrologi Indonesia (PERNEFRI, 2017) yaitu jumlah pasien hemodialisis baru berjenis kelamin laki-laki $(56 \%)$ sedikit lebih banyak dari perempuan $(44 \%)$.

Menurut Lestari (2017) menyatakan bahwa pembentukan batu ginjal lebih banyak diderita oleh laki-laki karena saluran kemih laki-laki lebih panjang sehingga pembentukan batu ginjal lebih banyak daripada perempuan. Laki-laki juga mempunyai kebiasaan yang dapat mempengaruhi kesehatan seperti merokok, minum kopi, dan alkohol yang dapat memicu terjadinya penyakit sistemik yang dapat menyebabkan penurunan fungsi ginjal. Sehingga pola kebiasaan yang buruk pada laki-laki dapat meningkatkan risiko terjadinya penyakit ginjal kronis.

\section{3) Pekerjaan}

Berdasarkan hasil penelitian diketahui bahwa pekerjaan responden tertinggi ialah Wiraswasta sebanyak 5 orang (25\%). Data RISKESDAS tahun 2013 menunjukkan bahwa Jumlah penderita gagal ginjal kronis tertinggi terjadi pada masyarakat dengan pekerjaan wiraswasta $(0,3 \%)$. Hasil ini berbeda dengan penelitian yang dilakukan oleh Hartini (2016) menyatakan bahwa proporsi pekerjaan tertinggi yang terkena gagal ginjal kronis dan menjalani hemodialisa ialah pada Pramono, Hamranani , Sanjaya / Pengaruh Teknik Relaksasi Otot Progresif terhadap ... Page $\mathbf{2 6}$ of $\mathbf{5 1}$ 
Jurnal IImu Keperawatan Medikal Bedah 2 (2), November 2019, 1-51

ISSN 2338-2058 (print), ISSN 2621-2986 (online)

kategori PNS berjumlah 29 responden (21,6\%). Menurut Delima, et al. (2016) menyatakan bahwa proporsi jenis pekerjaan terbanyak adalah tidak bekerja (35,9\%).

Berbagai jenis pekerjaan akan berpengaruh pada frekuensi dan distribusi penyakit. Tanpa disadari bahwa pekerjaan dapat menyebabkan penyakit ginjal seperti pekerja kantoran yang duduk terus menerus sehingga menyebabkan terhimpitnya saluran ureter pada ginjal. Di samping itu, intensitas aktivitas sehari-hari seperti orang yang bekerja di panasan dan pekerja berat yang banyak mengeluarkan keringat lebih mudah terserang dehidrasi. Akibat dehidrasi, urin menjadi lebih pekat sehingga bisa menyebabkan terjadinya penyakit ginjal (Rohma, 2015).

\section{4) Tingkat Pendidikan}

Berdasarkan hasil penelitian pada diketahui bahwa sebagian besar responden berpendidikan SMA (45\%). Pendidikan mempengaruhi pengetahuan seseorang mengenai gagal ginjal kronik dan efek samping yang terjadi apabila menjalani terapi hemodialisis. Seseorang yang tidak memiliki cukup pengetahuan kemungkinan akan merasakan tekanan saat menjalani hemodialisis. Seseorang dengan pendidikan tinggi cenderung akan mendapatkan informasi, baik dari orang lain maupun dari media massa. Semakin banyak informasi yang diperoleh semakin banyak pula pengetahuan yang didapat tentang kesehatan (Notoatmodjo, 2010). Tingkat pendidikan merupakan salah satu hal terpenting pada seseorang dalam menghadapi suatu masalah. Seseorang akan lebih siap menghadapi masalah seiring tingkat pendidikannya yang semakin tinggi maka semakin banyak pula pengalaman hidup yang dimilikinya (Lestari, 2017).

Penelitian yang dilakukan oleh Hanum, Nurchayati, \& Hasneli, (2016) menunjukkan bahwa proporsi tingkat pendidikan penderita Gagal ginjal kronik yang menjalani Hemodialisa terbanyak ialah SMA (30\%). Hal tersebut didukung juga oleh penelitian dari Dewi (2015) dimana jumlah pasien hemodialisis terbanyak berasal dari tingkat pendidikan menengah atau SMA $(36,7 \%)$. Tingkat pendidikan merupakan salah satu unsur yang sering dilihat hubungannya dengan kesakitan dan kematian, karena hal tersebut dapat mempengaruhi berbagai aspek kehidupan termasuk pemeliharaan kesehatan (Notoatmodjo, 2007 dalam Sitiaga, 2015).

\section{5) Status Perkawinan}

Berdasarkan hasil penelitian menunjukkan bahwa sebagian besar responden berstatus sudah kawin (90\%). Penelitian yang dilakukan oleh Bosniawan (2018) dimana status pernikahan Pramono, Hamranani , Sanjaya / Pengaruh Teknik Relaksasi Otot Progresif terhadap ... Page 27 of 51 
Jurnal IImu Keperawatan Medikal Bedah 2 (2), November 2019, 1-51

ISSN 2338-2058 (print), ISSN 2621-2986 (online)

menunjukkan sebagian besar responden telah menikah sejumlah 79 responden (85\%). Status pernikahan akan erat kaitannya dengan tanggung jawab keluarga yang kemudian bisa berpengaruh pada gaya hidup yang tidak sehat seperti tidak selektif memilih makanan dan jam kerja lembur yang padat. Hal ini tentu saja akan meningkatkan resiko terkena berbagai macam penyakit yang salah satunya adalah penyakit ginjal kronik (Utami, 2015).

\section{B. Pengaruh Teknik Relaksasi Otot Progresif terhadap Tingkat Kecemasan Pasien Hemodialisis}

Tabel 3. Gambaran Tingkat Kecemasan Responden di Ruang Hemodialisa RSUD Wonosari Tahun 2018 ( $\mathrm{n}=20)$

\begin{tabular}{clcccc}
\hline No & Tingkat Kecemasan & \multicolumn{2}{c}{ Pretest } & \multicolumn{2}{c}{ Posttest } \\
\cline { 3 - 6 } & & $\mathrm{f}$ & $\%$ & $\mathrm{f}$ & $\%$ \\
\hline 1 & Tidak Ada Kecemasan & 0 & 0 & 14 & 70 \\
2 & Kecemasan Ringan & 20 & 100 & 6 & 30 \\
3 & Kecemasan Sedang & 0 & 0 & 0 & 0 \\
\hline & Jumlah & 20 & 100 & 20 & 100 \\
\hline
\end{tabular}

Berdasarkan tabel 3 menunjukkan bahwa saat pretest, seluruh responden mengalami kecemasan ringan sebanyak 20 orang (100\%) dan pada saat posttest sebagian besar responden tidak mengalami kecemasan sebanyak 14 orang (70\%). Sehingga, terdapat penurunan jumlah responden sebanyak 6 responden dari kecemasan ringan sebelum dilakukan tindakan teknik relaksasi otot progresif ke tidak ada kecemasan setelah dilakukan teknik relaksasi otot progresif.

Tabel 4. Hasil Analisa Pengaruh Teknik Relaksasi Otot Progresif terhadap Tingkat Kecemasan Pasien Hemodialisis di RSUD Wonosari Tahun 2018 (n=20)

\begin{tabular}{lcc}
\hline & Mean Z Rank & $\mathrm{P}$ \\
\hline Kecemasan Pretest & $-3,742$ & 0,000 \\
Kecemasan Posttest & & \\
\hline
\end{tabular}

Berdasarkan tabel 4 menunjukkan hasil analisa menggunakan uji wilcoxon diperoleh hasil $p=0,000(\alpha=0,05)$. Hal ini menunjukkan adanya perbedaan tingkat kecemasaan yang signifikan antara sebelum dan sesudah pemberian terapi relaksasi otot progresif pada pasien hemodialisis. 
Jurnal IImu Keperawatan Medikal Bedah 2 (2), November 2019, 1-51

ISSN 2338-2058 (print), ISSN 2621-2986 (online)

Hasil penelitian ini menunjukkan bahwa saat pretest, seluruh responden mengalami kecemasan ringan yakni sebanyak 20 orang (100\%) dan pada saat posttest sebagian besar responden tidak mengalami kecemasan sebanyak 14 orang $(70 \%)$. Terdapat penurunan jumlah responden sebanyak 6 responden dari kecemasan ringan sebelum dilakukan tindakan teknik relaksasi otot progresif ke tidak ada kecemasan setelah dilakukan teknik relaksasi otot progresif. Hasil analisa lebih lanjut menunjukkan terdapat perbedaan tingkat kecemasaan antara sebelum dan sesudah pemberian terapi relaksasi otot progresif pada pasien hemodialisis dengan nilai $\mathrm{p}=0,000$ $(\alpha=0,05)$.

Hemodialisis adalah salah satu terapi pengganti ginjal yang dilakukan pada pasien penyakit ginjal kronik tahap akhir. Prinsip dasar dari terapi ini adalah dengan cara memindahkan zat-zat toksik melalui alat yang disebut dializer dan terapi hemodialisa harus dilakukan seumur hidup pada penderita penyakit ginjal kronik tahap terminal (Black \& Hawks, 2014). Pasien yang menjalani hemodialisis biasanya mengalami perasaan ambivalen terhadap proses hemodialisis yang sementara dijalaninya yaitu positif berupa bahagia yang diekspresikan secara bebas dan perasaan negatif meliputi rasa cemas dan kekhawatiran akan penyakit yang dialaminya (Cecilia, 2011). Sehingga berdasarkan uraian di atas terdapat hubungan antara tindakan hemodialisis dengan kecemasan pasien hemodialisis. Hal tersebut didukung dengan penelitian yang dilakukan oleh Musa (2015) pada pasien yang menjalani tindakan hemodialisa di RSUP Prof Dr.R.D Kandou Manado dimana terdapat hubungan antara tindakan hemodialisa dengan tingkat kecemasan klien gagal ginjal dengan hasil uji chi-square dengan nilai 0,000 lebih kecil, dilihat dari tingkat kemaknaan $95 \%(a=0,05 ; \mathrm{p}<0,05)$.

Kecemasan saat tindakan hemodialisis dapat dikurangi dengan beberapa terapi penurun kecemasan baik terapi farmakologi maupun non-farmakologi. Salah satu terapi non-farmakologi yang dapat mengurangi kecemasan ialah dengan menggunakan tehnik relaksasi otot progresif. Relaksasi otot progresif adalah latihan terinstruksi yang meliputi pembelajaran untuk mengerutkan dan merilekskan kelompok otot secara sistemik, dimulai dengan kelompok otot wajah dan berakhir pada otot kaki. Tindakan ini biasanya memerlukan waktu 15-30 menit, dapat disertai dengan intruksi yang mengarahkan individu untuk memperhatikan kelompok otot yang direlaksasikan (Johnson, 2005).

Praptini, Sulistiowati, dan Suarnata (2009) dalam penelitiannya mengatakan bahwa Pramono, Hamranani , Sanjaya / Pengaruh Teknik Relaksasi Otot Progresif terhadap ... Page 29 of $5 \mathbf{1}$ 
Jurnal IImu Keperawatan Medikal Bedah 2 (2), November 2019, 1-51

ISSN 2338-2058 (print), ISSN 2621-2986 (online)

relaksasi otot progresif akan menghambat peningkatan saraf simpatetik, sehingga hormon penyebab disregulasi tubuh dapat dikurangi jumlahnya. Sistem saraf parasimpatik, yang memiliki fungsi kerja yang berlawanan dengan saraf simpatik, akan memperlambat atau memperlemah kerja alat-alat internal tubuh. Akibatnya, terjadi penurunan detak jantung, irama nafas, tekanan darah, ketegangan otot, tingkat metabolisme, dan produksi hormon penyebab stres. Seiring dengan penurunan tingkat hormon penyebab stres, maka seluruh badan mulai berfungsi pada tingkat lebih sehat dengan lebih banyak energi untuk penyembuhan (healing), penguatan (restoration), dan peremajaan (rejuvenation).

Penelitian ini juga didukung oleh Pratama (2017) yang menyatakan bahwa latihan relaksasi otot progresif yang dikombinasikan dengan teknik pernapasan yang dilakukan secara sadar dan menggunakan diafragma, memungkinkan abdomen terangkat perlahan dan dada mengembang penuh. Teknik pernapasan tersebut, mampu memberikan pijatan pada jantung yang menguntungkan akibat naik turunnya diafragma, membuka sumbatan-sumbatan dan memperlancar aliran darah ke jantung serta meningkatkan aliran darah ke seluruh tubuh. Aliran darah yang meningkat juga dapat meningkatkan nutrien dan $\mathrm{O}_{2}$. Peningkatan $\mathrm{O}_{2}$ di dalam otak akan merangsang peningkatan sekresi serotonin sehingga membuat tubuh menjadi tenang dan mengurangi kecemasan.

Kelebihan penelitian ini bahwa relaksasi otot progresif efektif dapat menurunkan kecemasan pada pasien penyakit ginjal kronik dan dapat diterapkan saat dilakukan tindakan hemodialisis. Keterbatasan penelitian ini bahwa terapi relaksasi otot progresif hanya dilakukan satu kali saja.

\section{KESIMPULAN}

Berdasarkan hasil riset ini dapat disimpulkan adanya penurunan tingkat kecemasan pasien hemodialisis antara sebelum dan sesudah pemberian terapi relaksasi otot progresif. Pemberian teknik relaksasi otot progresif efektif untuk menurunkan tingkat kecemasan pada pasien hemodialisis di RSUD Wonosari.

\section{DAFTAR PUSTAKA}

Alfiyanti, N.E., Setyawan, D., Argo, M., \& Kusuma, B. (2014). Pengaruh relaksasi otot progresif terhadap tingkat depresi pada pasien gagal ginjal kronik yang menjalani hemodialisis di unit hemodialisa RS Telogorejo Semarang. E-Journal Stikes Telogorejo. 
Jurnal IImu Keperawatan Medikal Bedah 2 (2), November 2019, 1-51

ISSN 2338-2058 (print), ISSN 2621-2986 (online)

http://ejournal.stikestelogorejo.ac.id/index.php/jikk/article/download/375/396

Bosniawan, A.M.A. (2018). Faktor-faktor determinan yang berpengaruh pada kualitas hidup penderita gagal ginjal kronik di RSUD Sukoharjo. http://eprints.ums.ac.id/59809/22/Publikasi\%20ilmiah.pdf

Cecilia. (2011). Hubungan tingkat stres dengan kualitas hidup pasien gagal ginjal kronik yang menjalani hemodialisa di RSUP Dr. M. Djamil Padang. Indonesia One Search. https://onesearch.id/Record/IOS3629.121

Dewi, S. P. (2015). Hubungan lamanya hemodialisa dengan kualitas hidup pasien gagal ginjal di RS PKU Muhammadiyah Yogyakarta. 1-11. http://digilib.unisayogya.ac.id/234/1/NasPub\%20_Hubungan\%20lamanya\%20HD\%20dg\% 20Kualitas\%20Hidup.pdf

Dharma, P. (2014). Penyakit ginjal deteksi dini dan pencegahan. Yogyakarta: CV. Solusi Distribusi.http://digilib.unisayogya.ac.id/234/1/NasPub\%20_Hubungan\%20lamanya\%20H D\%20dg\%20Kualitas\%20Hidup.pdf

Hanum, R., Nurchayati, S., \& Hasneli, Y. (2016). Pengaruh pendidikan kesehatan secara individual tentang pembatasan asupan cairan terhadap pengetahuan tentang pembatasan cairan dan IDWG (Interdialytic Weight Gain) pada pasien hemodialisis. Jurnal Online Mahasiswa, 2 (2), 1427-1434. Perpustakaan Fakultas Keperawatan Universitas Riau https://jom.unri.ac.id/index.php/JOMPSIK/article/view/8316/0

Johnson, J. . (2005). Prosedur perawatan di rumah, pedoman untuk perawat. Jakarta: EGC

Kozier, B., Erb, B. \& S. (2011). Buku ajar fundamental keperawatan : konsep, proses, \& praktik. Jakarta: EGC

Lestari, A. (2017). Gambaran tingkat kecemasan pasien gagal ginjal kronis yang menjalani hemodialisis berdasarkan kuesioner Zung Self-Rating Anxiety Scale di RSUD Wates Tahun 2017. (6),

$67-72$. http://repository.unjaya.ac.id/2192/2/ASRI\%20LESTARI_2213085_pisah.pdf

Nursalam. (2011). Konsep dan penerapan metodologi penelitian ilmu keperawatan. Jakarta: Salemba Medika

Pailak, H., Widodo, S., Studi, M. P., Keperawatan, I., Telogorejo, S., Pengajar, S., ... Test, M. (2013). Perbedaan pengaruh teknik relaksasi otot progresif dan napas dalam terhadap tingkat kecemasan pada pasien pre operasi di Rumah Sakit Telogorejo Semarang. E-Journal StikesTelogorejo.http://ejournal.stikestelogorejo.ac.id/index.php/ilmukeperawatan/article/vi ew/171

Pernefri. (2016). Report of Indonesian Renal Registry 2015. https://www.indonesianrenalregistry.org

Pernefri. (2017). 10th Annual Report Of Indonesian Renal Registry. https://www.indonesianrenalregistry.org

Praptini, K.D., Sulistiowati, N.M.D., dan Suarnata, I. (2009). Pengaruh relaksasi otot progresif terhadap tingkat kecemasan pasien kemoterapi di Rumah Singgah Kanker Denpasar. Online Journal Universitas Udayana. https://ojs.unud.ac.id

Pratama, B. (2017). Pengaruh relaksasi otot progresif terhadap penurunan tingkat kecemasan pada ibu bersalin fase laten di RSU PKU Muhammadiyah Bantul Yogyakarta. (6), 67-72. http://repository.unjaya.ac.id/2029/2/BUDI\%20PRATAMA_2212017_pisah.pdf

Rahmi, W. (2008). Gambaran tentang tingkat kecemasan pasien yang pertama kali menjalani hemodialisa di ruang hemodialisa RS Dr. M. Djamil Padang. Repository Universitas Andalas. http://repository.unand.ac.id/5650/

Pramono, Hamranani , Sanjaya / Pengaruh Teknik Relaksasi Otot Progresif terhadap ... Page $\mathbf{3 1}$ of $\mathbf{5 1}$ 
Rohma, A. (2015). Penyebab gagal ginjal akut dan kronik. Retrieved from https://halosehat.com/penyakit/penyakit-ginjal/penyebab-gagal-ginjal

Sitiaga, S. (2015). Hubungan tingkat pendidikan, pengetahuan, dan dukungan keluarga dengan asupan protein pasien Gagal Ginjal Kronik (GGK) yang menjalani Hemodialisa (HD) rawat jalan di RSUD Kabupaten Sukoharjo. E-Prints Universitas Muhammadiyah Surakarta. http://eprints.ums.ac.id/40497/15/HALAMAN\%20DEPAN.sri.pdf

Suyamto. (2009). Pengaruh relaksasi otot dalam menurunkan skor kecemasan T-TMAS mahasiswa menjelang ujian akhir program di Akademi Keperawatan Notokusumo Yogyakarta. Berita Kedokteran Masyarakat. $25 \quad$ (3), 142-149. https://journal.ugm.ac.id/bkm/article/view/3561

Tjekyan, S. (2014). Prevalensi dan faktor risiko penyakit ginjal kronik di RSUP Dr. Mohammad Hoesin Palembang tahun 2012. Majalah Kedokteran Sriwijaya; 46 (4), 275-282. https://ejournal.unsri.ac.id/index.php/mks/article/view/2719

Utami, G. T. (2015). Hubungan dukungan keluarga dengan kualitas hidup pasien gagal ginjal kronik yang menjalani terapi hemodialisis di RSUD Arifin Achmad Pekanbaru. Jurnal Online Mahasiswa. Perpustakaan Fakultas Keperawatan Universitas Riau. https://jom.unri.ac.id/index.php/JOMPSIK/article/view/5172 